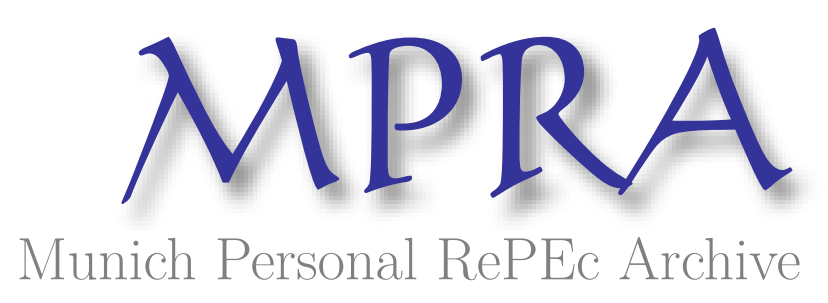

\title{
Different Theoretical Approaches about European Studies
}

\author{
Buda, Mariana \\ University of Oradea
}

2017

Online at https://mpra.ub.uni-muenchen.de/91410/

MPRA Paper No. 91410, posted 22 Jan 2019 10:57 UTC 


\title{
Different Theoretical Approaches about European Studies ${ }^{1}$
}

\section{Mariana BUDA}

\begin{abstract}
The European Studies, as a discipline of study or specialization, is no longer a new-entry in today's Higher Education. All the European countries, but even countries from the others continents, have introduced this discipline in their curricula. The aim of this article is to present and to analyse different theoretical approaches that have existed during the time in Europe and have conducted to the specialization of European Studies that we know today. The Bibliography in this domain is much extended, that's why we assume the risk and we do not pretend to be exhaustive with this classification. Otherwise, our study is a faithful representation of a theoretical basis.
\end{abstract}

Key words: European Studies, European Union studies, European integration studies, core curricula in European Studies, teaching European Studies

Generally, the European Studies focuses on the analysis of national and transnational changes on the European continent, with an emphasis on the European integration and European construction as a central theme (González, Wagenaar, 2005: 19). The definition of this field is also closely linked to events taking place in the contemporary age and the curricula of European Studies is subject of constant updating and evolution. The European Studies are considered to be both multidisciplinary and interdisciplinary studies at the same time. However, there are some differences related to the structure, content and approaches to the teaching and learning of European Studies, depending on the national traditions, but also on the faculties or departments where these study programs are being held.

Nowadays, there are differences and different ways of approaching the teaching and the learning of European Studies, depending on the country where they are taught, because the countries of European Union have a different view on the process of integration (González, Wagenaar, 2005: 19). This diversity is part of the European Studies and we think is a mistake to impose uniformity in this field. Despite that, there are similarities between the objectives of the European study programs and the skills that the graduates have to acquire while completing their studies.

This paper is the product of the desire to have a general overview about all the theories that have guided the European Studies to their actual shape. On the other hand, this study is also an overview of the different specialties of European Studies in Europe. The paper does not claim to be exhaustive. It would, however, reflect a state of fact and an existing reality, an inventory of the current resources and it is a tool able to reflect a new approach and the dynamic of a field of study. It is also important to underline the fact that this study will only make references to the European Studies in university education; it is not within the scope of this paper to cover said studies at high-school level or other levels of study.

\section{Conceptual delimitations regarding the terminology}

The new millennium brings changes in the field of education, especially with regard to higher education. Changes are multiple, and so are the approaches. The first step could be considered the implementation of the Bologna process, a major university reform process. Regarding the field of European Studies, we could talk about the theorization of the field: there are more and more articles and studies on European Studies; there is a difference on how the European Studies are being referred to. They are no longer simply called European Studies, but European integration studies or studies about European unity or European Union studies. A real explosion of these studies is remarkable especially after 2000, when the countries in the process of joining the EU are playing along the game with the others countries and when we are actually the witnesses of a real diversification of reflections on the European

\footnotetext{
${ }^{1}$ Research based on the PhD Thesis of the author
} 
Agenda. This is also the moment when it starts to appear the interrogations on the new university course (Horga, Buda, 2012:8) and thus, there is more and more used the syntagm of European Union studies. It is also the moment when many authors set out the question of embracing all European Studies in one fundamental field: should they fall under the field of political studies, or social sciences, or humanities? The questions are justified in view of their diversity, but especially given that European Studies are by definition multidisciplinary.

The extensive existing expertise in European Studies, as well as the numerous specialized studies that have been written, give us the opportunity to present a rich bibliography in the field. By going through the literature and synthesizing the main studies in the vast field of the European Studies, we have noticed that they are revolving around some essential issues.

First we have followed the literature that refers to the definitions of the European studies, thus making the corresponding conceptual boundaries since the beginning. Today we are confronted with concepts such as European Studies, European Union studies, European integration studies, as we have mentioned above. The debate on the used terminology is varied. Michael Smith from Queen's University of Belfast, UK, believes that European Union studies (Smith: 2003: 3) are the centre of the European Studies. On the other hand, Chris Rumford \& Philomena Murray (Rumford, Murray: 2003: 86), state that European Union studies are actually European integration studies. If the studies about the European integration aim at the analysis of the phenomena related to the common market and, consequently, all the other phenomena connected, the European Union studies are more than an analysis of the market. Those represent a social model as well (Rumford, Murray, 2003: 88; Delanty, 1998: 3). The European Union can be just a framework for globalisation, anchored in solidarity and sustainability (European Council, 2001). On the other hand, the topic of multilevel governance started to be more and more present in the European Studies, and particularly since the debate around the governance took consistency (Hooghe, Marks, 2001). The model of multilevel governance permitted to detach the European Union studies from the European integration studies (Murray, 2000), because the European Union studies allow the development of other kind of approaches like: studies about regional policy, studies about the relation between globalization and European Union, studies about social policy, etc.

European integration studies are those studies or disciplines that in their content refer only to the European integration process. We believe that this kind of study was only a step towards the further development of European-oriented Studies, because European integration was one of the first major processes that Europe and the European Union went through. The broadest of concepts is certainly the European Studies. European Studies are multidisciplinary and interdisciplinary at the same time, and their purpose is to describe, conceptualize, explain and understand a reality across Europe that cannot be understood and summarized by a single discipline. European Studies refer to all the realities in Europe, not just those related to the European Union or European integration. The point of their convergence is the European unity. By European unity, we understand all those studies that promote the European dimension in education, that is, that contributes to the formation of the consciousness of belonging to Europe under any of the following aspects: geographic, historical, political, economic, administrative, religious, etc. Thus, European integration studies include only those disciplines that refer strictly to the integration process, to the enlargement of the EU, i.e. to the accession process and its consequences on all levels.

Also Gaby Umbach and Bruno Scholl from the Univeristy of Koln, Germany, in their researches related to a common curriculum for all the specializations in European Studies, make a clear distinction between the concepts frequently used: European Union studies, European integration studies and European Studies. The European Studies are the most general ones and include the other two categories; they are generic studies and they refer to all aspects related to Europe: culture, legislation, economy, languages, etc. The European Union studies are more limited studies and they refer strictly to the events related to the EU, starting with its creation, its development and ending with the most recent topics. These studies do not refer to larger contexts like the European culture, European economy, etc, disciplines which would take into discussion elements that do not belong to the EU, but to the European space in general. The most reduced studies are those about the European integration. They are included by the 
European Union studies, because the integration is a process that belongs to the creation and the development of the EU (Umbach, Scholl, 2003). Consequently, we can set up the following scheme:

$$
\mathrm{ES}^{2} \leftarrow \mathrm{EUS}^{3} \leftarrow \mathrm{EIS}^{4} .
$$

\section{The development of a curriculum in European Studies}

Probably the first study about uniformity in the teaching about Europe was conducted by Margaret Shennan in 1986 and published in the journal The Social Sciences. Margaret Shennan's project focusses on three aspects (Shennan, 1986:9). The first refers to the knowledge that students must have, the second to the skills they need to assume and third to the attitudes and values that must be transmitted by the studies about Europe. The ideas proposed by the author come after a few personal observations of Margaret Shennan, who noticed that in Europe, the studies about Europe are taught chaotic, without having common parts or even basic ideas. Thus, whether these studies are taught in the framework of history, foreign languages, geography, literature, political science, they must have common objectives and goals (Shennan, 1986:8).

Regarding the discussions and the scientific production in the field of a core curriculum in European Studies, we find two types of approaches. On one hand, there are the supporters of the idea of a basic curriculum in European Studies, understood as a list of items considered essentials for the knowledge in the domain of European Studies, which also contains a list of objectives and teaching methods. And on the other hand, we find the proposal of a learning companion, defined as a kind of book or guide that provides information on a particular topic or explains how to do a certain thing. Therefore, the study guide in European Union studies will provide information about a deeper perception of European integration, materials and resources for teaching and learning this subject.

Wolfgang Wessels, Ingo Linsenmann and Susan Hägele propose another interesting research study called Teaching European Integration. A Core Curriculum on European Integration Studies; Basic assumptions and proposals. The article of the three authors is part of a wider research, a project called "Developing a core curriculum of European integration", funded by the European Commission. The authors start from the statement that it is required a basic curriculum of European integration studies and the political challenges require the need for courses on European Union. The European Union is the crucial element of the political architecture of Europe and therefore for all the political systems in Europe. They do not want to harmonize the resources, but to establish frameworks, that is a frame in which you can make applicable changes also across borders, whether national or disciplinary (Wessels, Linsenmann, Hägele, 2001:4). A core curriculum, as the authors understand, consists of a list of items considered to be essential knowledge in a given field. The article is based on finding those objectives and purposes to form a curriculum in European integration studies and those educational methods that can be applied for the acquisition of knowledge. Thus, the authors suggest the following directions of study regarding the European integration studies:

- History of European integration process

- Theoretical approaches of European integration

- Evolution of EU system

- EU as a system of multilevel networks, administration, governance

- Fundamental Law of EU

- Institutions

- Procedures

- Policies

- Types of governance

\footnotetext{
${ }^{2}$ European Studies

${ }^{3}$ European Union Studies

${ }^{4}$ European Integration Studies
} 
- Further development of the integration process

- EU's role in the world.

Sure, the list proposed by the authors is not exhaustive and it is open for revisions (Wessels, Linsenmann, Hägele, 2001:5-6). As a conclusion of their research, the authors stress that interdisciplinarity is the key for the study of European integration. In addition, taking into account the fact that European integration is a quicksand, the teaching methodology is required to be more sophisticated than normal.

Gaby Umbach and Bruno Scholl from the University of Köln, Germany, made another study on core curriculum in European studies. The study that the two authors propose is a natural continuation of the study conducted by Wolfgang Wessels, Ingo Linsenmann and Susan Hägele and mentioned above. Umbach and Scholl explain the need of a core curriculum in European integration studies. In their research they also exemplify their model of core curriculum. Thus, it can be made once again the distinction between the two types of studies, those about the European integration and those about the European Union. The European integration studies cover all events centred on the European integration. The European Union studies cover all the events centred on European Union. The overview is clearer now.

The two authors of the research study Towards a Core Curriculum in European Union Studies start their investigation from the finding that the study programs in European Union studies at Bachelor level and Master level have become more and more numerous in the last decade, not only in the framework of political sciences, but also in other fields of study. In addition, the European Union has become a key topic both in the frame of traditional courses and conventional courses. The purpose of this research is to explore how these experiences could contribute to a core curriculum containing basic items and relevant methods for the European Union studies and how these resources could be shared in order to facilitate the teaching (Umbach, Scholl, 2003:71). The mentioned study begins with an overview both of the European Agenda with reference on the development of the curriculum and on the academic and political challenges associated with the teaching about the EU. Finally, the authors propose some conclusions on how it should look a good core curriculum and offer some suggestions on how the professors of European Union studies could use web resources in their teaching, but also on how New Information and Communication Technologies (NTIC) could facilitate the teaching.

To answer the questions related to the concept of core curriculum in European Union studies, the authors state that this, in their vision, is like a list of items considered to be essential for the knowledge and the understanding of European Union studies. Therefore, the development of curricula in EU studies should focus initially on the core objectives proposed by the curriculum and then on the teaching methods. This is the reason why, for the academic curricula, the European Union studies should be treated either as area studies (EU being the case, the situation) or as a horizontal theme (EU representing the theme) in several disciplines and courses (Umbach, Scholl, 2003). On the other hand, there are some practical arguments against the existence or creation of core curriculum in European Union studies. The first argument would be the rigid content that these core curricula would impose, but also the materials and the methods that would come by default. Secondly, the flexibility of the professors should not be restricted by a fixed curriculum that would block the variation and the competition between universities.

Proving that a core curriculum in European Studies may have more disadvantages than advantages, Gaby Umbach proposes the idea of a teaching companion. Thus, the study entitled Responding to the European Curricula Development: a ,teaching companion” in EU studies, is part of another phase of the project initiated by the University of Köln, EspNet Episteme II, and follows the previous studies about a core curriculum in European Union studies. This time the author proposes the creation of a "teaching companion". A "teaching companion" is defined as a kind of book that provides information on a particular topic or explains how to do a certain thing. Therefore, this learning guide in European Union studies should provide information regarding a deeper perception on European integration, but also materials and resources for teaching and learning about this subject (Umbach, 2003:23). 
Concerning the debates and scientific production in the field of core or basic curricula in European studies, we find two types of approaches. On the one hand, there are supporters of the basic curricula idea in European Studies, understood as a list of items considered essential for the knowing in the field of European Studies, which also includes a list of objectives and teaching methods. On the other hand, there is the proposal of a teaching companion, defined as a kind of book or guide that provides information on a particular theme or explains how to do something. Therefore, the learning guide for European Union studies will provide information on a deep perception of European integration, as well as materials and resources for teaching and learning this theme. Last but not least, there are the followers of the idea that any curriculum in higher education, but especially a European curriculum, must go through the process of Europeanization, through the process of a permanent change and adaptation especially to political and economic realities. By demonstrating that a common curriculum in European studies could have more disadvantages than advantages, Gaby Umbach suggests that a companion or learning guide could be a suitable solution for European Studies.

Two other researchers, Heather Field and Ian Bache, propose two other studies regarding the curricula of European Studies and the relationship between the curricula and the process of Europeanization.

Thus, given the recent interest of the academic environment on a special curricula dealing with the studies on European integration, Heather Field, author of the article European Integration Curricula and „Europeanisation”: Alternative Approaches and Critical Appreciation proposes a study about the relationship between these concerns and the process of "Europeanization". She proposes several "alternative approaches" to the studies teaching European integration and the need to promote a critical analysis. To some extent, some aspects of this approach can be considered Anglo-Saxon or Scandinavian approaches considered to be opposing to the approaches in the EU's member states (Field, 2001:1). The aspect very well argued in this research is that an appropriate approach on the teaching of European integration is covering not only the key events of the integration process, but also the various debates on the subject and their implications. An approach of the teaching European integration studies aiming at standardization and to eliminate problems, risks losing sight of important aspects and suffocate other approach, which would risk the creation of better or worse Europeans, depending on the teaching (Field, 2001:1). The European integration studies should not be uniform, despite the Europeanization process, in order to maintain the diversity. The basic idea that promotes Heather Field is that education in European integration field should be designed to provide to the students, on one hand the understanding of the main ideas and approaches relevant for European integration, and on the other hand to have the capacity and skills to be able to test these theories and approaches (Field, 2001:9).

Ian Bache, in his study Europeanisation and Higher Education: Towards a Core Curriculum in European Studies? promotes the idea that the Europeanization of the higher education should be understood in the context of political and economic imperatives, thus creating an even closer union among European countries. In this context of Europeanization, there is the risk that the debates on the academic movements to create a core curriculum in European Studies to be subject of economic and political reasons which would undermine the potential pedagogical benefit of a European cooperation in this field.

The debates around the issue related to the Europeanization of education focuses primarily on what it's necessary to be studied in universities and how. European Union studies include a number of themes to be studied necessarily, although the effects of Europeanization are viewed differently by the States (Bache, 2004:3). In general terms, Ian Bache states that the development of the curriculum must be understood in the context of the changing relationship between higher education and society. While, from the historical point of view, the influence of dominant social institutions such as the church or the monarchic power exercised more an indirect power on universities, today the higher education institutions are directly influenced by the State and the public institutions adopted the language of the society. In particular, the higher education was quickly transformed from institution in society, in an institution of the society (Bache, 2004:4). 
Continuing our investigations on European Studies, we noticed the outline of different teaching models for these studies. Britain is perhaps the country with the greatest attention to the theory on these studies, which is why the literature is vast in this country. In particular, we can talk about a large number of research papers on European Studies in the UK. The one who analysed this area the most was Michael Smith, a professor at Queen University in Belfast. He proposes several works on European Studies in the UK, which is why we can say that a British model emerges out of these studies. Since the beginning of this study program in the UK, it has been led by three defining key factors. Firstly, European Studies have been a response to the belief that if the UK is ready to enjoy the benefits of accession, it urgently needs specialists in the field able to solve both administrative and economic problems that come as a consequence of EU membership. Secondly, European Studies have been conceived as a way of understanding the importance of interculturality. The latter has been seen as the focal point of European Studies, especially through the promotion of foreign languages among British students. Promoting languages also promotes mobility in other member countries, thus encouraging deeper knowledge of other countries' culture and developing students' communication skills. And, thirdly, the distinctive feature of European Studies has always been the commitment to interdisciplinarity. As a study program, it has always been thought that in order to get to the complexities of the events taking place in European societies and especially those associated with European integration, special and distinct methods are needed, especially in the field of human sciences and social issues. In practice, however, the development of European study programs was rather a special force within universities that created more flexible, less rigid structures, often exceeding the rigid and conservative intellectual boundaries between disciplines (Smith: 2003).

\section{Teaching and learning European Studies}

Along with the various discussions around the European Studies, teaching them in institutions represents a separate issue and a very important debate in their dissemination among students. Learning about European issues appears inevitable for the future of political sciences (Georgakakis, Smith, 2004 :5). And it is important to pay particular attention to the teaching method of European Studies. Taking into account that teaching, learning and assessment are the basic components of any knowledge transfer process, we have focused on the teaching methods of the European studies. When we talk about teaching European studies, we always ask ourselves what we need to teach: should it be political science about Europe? European institutions? European Union? European policy? A European Polity Course? Political Sociology of the European Union? The teaching of this has its own unique characteristics that lead us to some preliminary reflections.

First of all, we cannot consider European studies as a sub-discipline, but still it is more than that (Georgakakis, Smith, 2004:11). The environment and the status of courses about Europe are very diverse depending on where they are being taught. There are both European Studies specializations, but also specializations of International and European Studies, as well as specializations with European dominance. Most specializations are at Bachelor and Master level, but at doctoral level they are still underdeveloped. Even the ones at Master level are undergoing constant developments and changes. What is observed at European level is that there are few courses specialized in the political science of the European Union (Georgakakis, Smith: 2004:12). This does not mean that European themes are absent from political science, but that they are present within a very diverse set of courses. For example, in public policy courses there is often a chapter on the Europeanization of public policies, but also on the matters of European policies. It is also the case of political sociology courses that always contain elements about European elections or the transformation of political professions. However, European Studies do not aim at creating a sub-discipline and still have some juxtaposition problems (Georgakakis, Smith: 2004:12). The development of European Studies is obvious alongside the time. Most of them present sociological or political approaches to European Studies, but interdisciplinarity or multidisciplinary presentations are always being used. We therefore observe that European Studies have always been the subject of debate both in terms of their content and in terms of their location within one 
or other classical, consecrated disciplines. We assess that the multidisciplinary approaches are best suited to treating any subject of European Studies, because by their very nature, European studies are a combined set of factors.

Another reference study regarding the teaching of European Studies is the volume edited by the prestigious publishing house Springer and entitled Teaching and Learning the European Union. Traditional and Innovative Methods, coordinated by Stefania Baroncelli, Roberto Farneti, Ioan Horga and Sophie Vanhoonacker. During the 14 chapters, the authors present different stages of European Studies, and different ways to teach them. The volume starts from the real challenges of European Studies, to inventory then the innovative methods of teaching and learning them. Between the newest methods of teaching and learning European Studies presented in the volume we can include: participation at EU's simulations (Jones, Bursens, 2014:157), distance learning as an alternative method for learning European Studies (Timuş, 2014:187), learning based on case studies (Maurer, Neuhold, 2014:199), learning through the mix of appropriate knowledge (Mihai, 2014: 217) or even learning through social networks (Farneti, Bianchi, Mayrgündter, Niederhauser, 2014:229).

Another important tool that has been perpetuating the teaching of European Studies, but especially the teaching of European integration studies was the Jean Monnet Action. The Jean Monnet Action is a European Commission's initiative which is grouping several types of structures: Jean Monnet Chairs, Jean Monnet Centres, permanent courses Jean Monnet, European modules and others. The Jean Monnet Action can support any university or higher education institution which wishes to introduce in their curricula new disciplines related to European integration (Belot, Brachet, 2004: 149-152).

Regarding the distribution of funding per discipline in 2004, it appears that the most funded are the disciplines related to Community Law comparing to those of Political Sciences, who are on the second place, then those related to the Economy and then the History. This high incidence of the Law on the study of Europe can be considered as an approach for a better knowledge of the legal order, because the European Union can be seen as a creation of the law through the treaties and through an institutional system whose main objective is the production of law (rules, directives, regulations, etc.) (Belot, Brachet, 2004: 153). Taking into account, however, the Jean Monnet chairs of the countries that joined the EU after 2004, there is a preponderance of disciplines in the economic field, suggesting the importance for these countries of the single market, of a free trade area or the belief of these countries that the EU' accession will have beneficial consequences for their economy (Belot, Brachet, 2004: 154).

European Studies have been a subject of study not only in countries within the European Union but also outside. As students in Europe are interested in American Studies, we also find students interested in studying Europe in the United States, this program being taught at prestigious universities. Switzerland, even though not a member of the European Union, is a country where there is a high interest in European Studies, but especially in the European policy and political sciences. Another interesting study about teaching European Studies outside the European Union is the one made by Angelo Santagostino from the University of Brescia, Italy, who carried out a review of European Studies in Turkey. Angelo Santagotino argues that European Studies in Turkey have undergone a broad development process in recent years, especially after the Helsinki Summit. At present, about one in three Turkish universities is engaged in research or teaching in the field of European integration. At the same time, Jean Monnet Action is very active in Turkey, especially after 2001. Thus, European Studies in Turkey can be characterized by a dual focus: on the one hand, on the territorial one, and on the other on the sectorial (Santagostino, 2004). Recently, the academic environment in the Republic of Moldova and the general public have shown an increasing interest in the field of European Studies, especially regarding the relation of the Republic of Moldova with the European Union (Iovu, Toderaş, 2006:3-4).

\section{Other theories about European Studies}

Towards the end we included the researches on European Studies programs that had a more particular approach. There is a rich expertise in European Studies, especially within professional 
associations created for this purpose, which provide interesting theories on European Studies, which are included in this part.

Ian Manners, the director of the Institute for International Studies in Copenhagen, Denmark, proposes the study entitled Europaian Studies about the European Studies that can be considered an answer to the question why there isn't a theorization of European Studies or a European theory. The answer that the author proposes from the beginning is that neither should be such a theory. The only need is for the recognition of European Studies as area studies, i.e. multidisciplinary studies and not disciplinary studies concentrated in another discipline.

Sure, there are many theories that try to explain contemporary Europe, as there are many disciplines that handle with different European issues, such as politics, sociology, economics, law and others that contain a lot of theorizing about Europe. What motivates the author to write this research is the concern on the "normalization" or "routine" on European Studies in different disciplines mentioned above, but without taking into account the new developments in the social sciences. He assumes that European Studies are not studies on contemporary Europe but it's a collective term for specific studies on Europe, so interdisciplinary studies, summary or integrative of certain knowledge (Manners, 2003: 67).

Area studies versus disciplinary studies is at the moment the problem that debilitate the European Studies and which is central to "trivializing" them or "normalize" them. Thus, European Studies require the existence of some transdisciplinary readings, both for the health and the wellbeing of the European Studies but also of the disciplinary studies. In support of his idea, Ian Manners gives the example of Martin Wight who asked the same question like him, only that he was referring to the International Relations, and namely why there is not a theory of International Relations. Similarly, Ian Manners tries to exemplify the reason for the inexistence of a European theory for the area studies. But he will not separate International Relations to Politics, as did Wight, but on the contrary, Manners proposes a multidisciplinary approach, i.e. the integration of theories of International Studies and Politics studies together with the study of social and natural sciences in a better way for the understanding of a "European theory". For the author, the "European theory" refers to a tradition of speculations about Europe, tradition that has been lost among the constituent parts of the whole, parts that represents different disciplines (Manners, 2003: 68).

Another important theory, with a direct influence on the academic production in the field of European Studies is the one proposed by Rosamond, who believes that any scientific activity which refers to the European Union is influenced by two types of stimuli, internal stimuli and external stimuli (Rosamond, 2007: 232). The same opinion is shared by the Professor Ioan Horga from the University of Oradea in his research dedicated to the analysis of European Studies curricula (Horga, 2012: 107).

The main point in the research of Ben Rosamond is the identification of two types of factors or stimuli that influenced the creation and development of the European Union studies. These are the internal factors and external factors. The external factors have stimulated the scientific production in the field of European Union in various ways. For example, the European Union enlargement, especially in significant moments for the integrity of the European Union system, coincides with phases of an intensive publishing activity in this area. Also, the evolution of the EU institutions attracted an abundant work in the scientific production (Rosamond, 2007: 239). Or, the events from the exterior, have initiated a request for their knowledge, concretized in different ways to transmit this knowledge. The same thing can be said of the attempts to develop coherent projects where to apply the approaches from the political economy field, multilevel governance, public administration and others (Rosamond, 2007: 241).

On the other hand, in his research, Ioan Horga analyses how internal and external stimuli influence directly the European Studies curricula. Based on the analysis of a database (Horga, 2012: 126128) that listed courses from 12 European countries, he demonstrates that, regarding the European Studies, they can be considered as a singular science, so they are not part of other sciences such as administrative studies or political sciences. Therewith, according to his investigations, he states that there is a flexible and differentiated curriculum for European Studies, so it is obvious the influence of internal factors within it. The analysis and explanations are multiple and complex. European Studies are analysed from the perspective of the subjects where might be applicable, i.e. legal studies, economic studies, 
administrative studies, historical studies, etc., both at the Bachelor and Master level. Although there are influences from all these disciplines, however, European Studies are considered a special field, interdisciplinary and multidisciplinary at the same time. Regarding the influence of external factors that are seen in the curricula of European Studies, the professor mentions that European Studies keep up with practical and theoretical developments in the European Union Agenda.

In the end it's important to mention another major international project in the field of European Studies, namely the SENT ${ }^{5}$ project, which settled up some directions in the field of European Studies. The SENT project was, maybe, the latest project that deals with the curricula of European Studies. SENT was an ambitious project, developed over a period of three years that had as main objective mapping the European Studies in Europe. The main results or outputs of the SENT project are published books, which represent a step forward in raising awareness on European Studies at European level, but also bringing them to a different level. The publications resulting from the project are, in our opinion, representative for the community of researchers in European Studies and a welcomed theoretical approach. These are: the volume „Analyzing European Union Politics” published by Federiga Bindi and Kjell Eliassen in 2011, the volume „Teaching and learning the European Union. Traditional and Innovative Methods” edited by Stefania Baroncelli, Roberto Farneti, Ioan Horga and Sophie Vanhoonacker in 2014, the volume „European Integration between History and New Challenges" edited by Ariane Landuyt in 2014, the volume „Integration through legal education. The role of EU legal studies in shaping the EU” published by Valentino Cattelan, the volume „Questioning the European identity/ies: deconstructing old stereotypes and envisioning new models of representation" edited by Vita Fortunati and Francesco Cattani in 2012, the volume „Ideas of Europe in National Political Discourse”, edited by Cláudia T. Ramos in 2011, the „Communication, Mediation and Culture in the Making of Europe”, edited by Juliet Lodge and Katharine Sarikakis in 2013 and the volume "Mapping European Economic Integration", edited by Amy Verdun and Alfred Tovias, also in 2013. Each volume has a different approach concerning the European Studies, demonstrating their diversity but also their interdisciplinarity.

The SENT project, through its results, might mark a new stage in the evolution of European Studies. Thus, we can talk about a period of maturity, settlement and classification of knowledge.

\section{Conclusions}

We believe that our work is useful especially in those faculties that teach European Studies, as it provides a picture of the current state of different theoretical approaches in European Studies, both with their positive and negative sides. A good knowledge of them is a starting point for improving the teaching and learning process, but also for the development of these studies, which require a continuous process of renewal and rehabilitation, according to their specificity. On the other hand, the novelty our work brings is precisely this analysis that so far has not been carried out. Thus, we can say that the work is both a starting point for future research and it presents the status quo of an existing reality.

Discussions about the place and role of the European Studies within the social sciences, especially the political ones, have brought about much dynamic debate over time. Although the purpose of this study is to put European research under one or another field of knowledge, it can be easily observed that there is an inclination of these studies towards the political science, but it shouldn't be confused with it. Interdisciplinary studies, primarily, but also multidisciplinary and transdisciplinary as they are today, the European Studies are an integral part of the higher education curricula.

Generally, the existence of European Studies is determined by the need to provide answers to complex problems and European challenges. Understanding European societies in their development from past to present impose the introduction of methods adopted from a variety of different disciplines. Given that Europe is a set of inter-connected societies, that have become even more diverse and more interlinked than any other geographic and political area, there must be increasingly more programs for European Studies as interdisciplinary structures and with a complex approach.

\footnotetext{
${ }^{5}$ SENT -The Network of European Studies
} 
In the end, we believe that education is one of the main pioneers in achieving democracy and we hope that European Studies offer the most appropriate means for finally reaching it. The scope of this paper is to present and to analyse different theoretical approaches that have existed during the time in Europe and have conducted to the specialization of European Studies that we know today. Although our study can be criticized from various aspects, we believe that this process can help to carry out much deeper, quantitative and / or qualitative research on European Studies not only in Europe, but also throughout the European Community and finally, that our efforts shall promote the necessary European dimensions in higher education. Moreover, we believe that, from what we have achieved so far, we can develop many other lines of research and investigation. Therefore, this paper should be considered as a starting point for further development, but also as a stimulating basis for future studies.

\section{References:}

- Bache, Ian (2004), Europeanisation and Higher Education: Towards a Core Curriculum in European Studies? Paper presented in the framework ESRC/UACES Study Group and Seminar Series on the Europeanisation of British Politics and Policy-Making, Sheffield, UK, 2004. Unpublished. http://aei.pitt.edu/1728/, Accessed November 20, 2017

- Baroncelli Stefania, Farneti, Roberto, Horga, Ioan, Vanhoonacker, Sophie (editors) (2014), Teaching and learning the European Union. Traditional and Innovative Methods. Springer

- Belot, Céline ; Brachet, Claire (2004), Enseigner l'Europe à travers l'Action Jean Monnet. Etat des lieux et pistes de réflexions in „Politique européenne. Enseigner l'Europe”, L'Harmattan, nr. 14, automne 2004

- Delanty, Gerard (1998), Social Theory and European Transformation: is There a European Society? in „Sociological Research Online”, vol.3, nr. 1

- European Council meeting in Lacken, Presidency conclusions, 14-15 December 2001. www.ue.eu.int/Newsroom/marketFrame.asp?, Accessed November 21, 2017

- Farneti, Roberto; Bianchi, Irene; Mayrgündter, Tanja; Niederhauser, Johannes (2014), The Network is the Message: Social Networks as Teaching Tools in Baroncelli Stefania, Farneti, Roberto, Horga, Ioan, Vanhoonacker, Sophie (editors), Teaching and learning the European Union. Traditional and Innovative Methods. Springer, 2014

- Field, Heather (2001), European Integration Curricula and „Europeanisation”: Alternative Approaches and Critical Appreciation, Paper presented in the framework of ECSA Seventh Biennial International Conference Madison, Wisconsin, 2001. Unpublished. http://aei.pitt.edu/2083/1/002235 1.PDF, Accessed November 20, 2017

- Georgakakis Didier; Smith Andy (2004), Enseigner l'Europe, in „Politique européenne. Enseigner l'Europe", L'Harmattan, nr. 14, automne 2004

- González, Julia; Wagenaar, Robert (coord.) (2005), Reference Points for the Design and Delivery of Degrees Programmes in European Studies, in "Tuning. European Studies for website". Publicaciones de la Universidad de Deusto, Spain. http://tuningacademy.org/wpcontent/uploads/2014/02/RefEuropeanStudies EU EN.pdf, Accessed November 21, 2017,

- Hooghe, Liesbet; Marks, Gary (2001), Multi-level Governance and European Integration, Lanhman, MD: Rowman \& Littelfield

- Horga, Ioan (2012), European and/or EU Studies Curriculum between Internal and External drivers, in "The Romanian Journal of International Relations and European Studies", nr. 1, Vol 12012

- Horga, Ioan; Buda, Mariana (2012), Analytical and Methodological Framework of Research in European and/or EU Studies Curriculum in The Romanian Journal of International Relations and European Studies , no. 1, vol1/2012 
- Horga, Ioan, Farneti, Roberto (2011), European and/or EU Studies Curriculum between Internal and External drivers in „EUSA Papers”, Network of European Union Centers of Excellence, 2011. http://euce.org/eusa/2011/papers/11d horga.pdf. Accessed November 20, 2017

- Iovu, Andrei; Toderaş, Nicoale (2006), Curriculum universitar şi recomandări bibliografice pentru publicul larg în domeniul Studiilor Europene in Studiul de necesitate "Europa Fundamentală", Chişinău

- Jones, Rebeca; Bursens, Peter (2014), Assessing EU Simulations: Evidence from the TransAtlantic EuroSim in Baroncelli, Stefania, Farneti, Roberto, Horga, Ioan, Vanhoonacker, Sophie (editors), Teaching and learning the European Union. Traditional and Innovative Methods. Springer, 2014

- Manners, Ian (2003), Europaian Studies, in „Journal of Contemporary European Studies”, Vol 11, No.1, 2003

- Maurer, Heidi; Neuhold, Christine (2014), Problem bassed Learning in European Studies in Baroncelli Stefania, Farneti, Roberto, Horga, Ioan, Vanhoonacker, Sophie (editors), Teaching and learning the European Union. Traditional and Innovative Methods. Springer, 2014

- Mihai, Alexandra (2014), Finding the right mix? Teaching European Studies Through Blended Learning in Baroncelli Stefania, Farneti, Roberto, Horga, Ioan, Vanhoonacker, Sophie (editors), Teaching and learning the European Union. Traditional and Innovative Methods. Springer, 2014

- Murray, Philomena (2000), European Integration Studies. The search for Synthesis, in „Contemporary Politics”, vol. 6, nr. 1, 2000

- Rosamond Ben (2007), European Integration and the social science of EU studies: the disciplinary politics of a subfield in "International Affairs", 83:1, 2007. http://wrap.warwick.ac.uk/1079/1/WRAP Rosamond 9570885-150709-rosamond ia 07.pdf.

Accessed November 25, 2017

- Rumford, Chris; Murray, Philomena (2003), Globalization and the Limitation of European Integration Studies: Interdisciplinary Considerations, in „Journal of Contemporary European Studies", vol. 11, no. 1

- Santagostino, Angelo (2004), European Studies in Turkey: present state and proposals for the future, in „European Stability Initiative. Berlin-Brussels-Istanbul”, 2004. http://www.esiweb.org/pdf/esi turkey tpq id 9.pdf. Accessed November 25, 2017

- Shennan, Margaret (1986), Goals or Teaching about Europe in „The Social Studies”, Ian/Feb. 1986, 77:1

- Smith, Michael (2003), The State of European Studies. Raport commissioned by the Standing Conference of Heads of European Studies, London, SCHES

- Timuş, Natalia (2014), Distance Learning as an Alternative Method of Teaching European Studies in Baroncelli Stefania, Farneti, Roberto, Horga, Ioan, Vanhoonacker, Sophie (editors), Teaching and learning the European Union. Traditional and Innovative Methods. Springer, 2014

- Umbach, Gaby (2003), Responding to the European Curricula Development: a "teaching companion" in EU studies, EpsNet Kiosk Plus, Vol. 1, No. 1

- Umbach, Gaby (2003), Responding to the European Curricula Development: a „teaching companion" in EU studies, EpsNet Kiosk Plus, Vol. 1, No. 1, June 2003

- Umbach, Gaby; Scholl, Bruno (2003) Towards a Core Curriculum in European Union Studies in „European Political Science Review”, epsNet Kiosck Plus, nr. 2.2

- Umbach, Gaby; Scholl, Bruno (2003), Do we need a core curriculum in european studies? European Political Science Review, epsNet Kiosck Plus, 1

- Wessels, Wolfgang; Linsenmann, Ingo; Hägele, Susane (2001), Teaching European Integration. A Core Curriculum on European Integration Studies; Basic assumptions and proposals, Paper communicated in the framework of ECSA Seventh Biennial International conference in Madison, Wisconsin, 31 May- 2 June 2001 